\title{
The political system of the European Union and the politological and political determinants of the activity of the EU Council and the European Council ${ }^{1}$
}

\section{The political system and the politicization and democratization of the EU}

\section{Partial polity}

The integration experience of EU member states, in which Poland has had its share for over a decade, allow a functionalist category of partial polity to be distinguished, which is rooted in the process of aggregation and acceleration of European integration initiated by the Maastricht Treaty on European Union. This category is a compromise and a response to interactions between member states and the supranational authority of the EU (Czachór, 2004).

These interactions are of particular importance from the point of view of the activity of the EU Council and the European Council. This is so because the European Union and its member states form a specific, and not fully legitimized, fragmented political system that is based on an unprecedented arrangement of powers. In a classic approach, this is a horizontal arrangement of relations between the institutions and many entities of the European Union, and a vertical one, whereby relations are regulated between the EU, nation-states and regions, as well as non-state entities, such as intra-state and international interest groups, including trade unions, entrepreneurial organizations, political parties and non-governmental organizations (Czachór, 2010, pp. 61-62).

As concerns the vertical aspect, the European Union's system is based on the division of power between the central authority of the European Council and the authorities of individual states gathered in the EU Council. The division of power is made here based on the rules of law as well as informal provisions and procedures. In the integration reality, the actual effectiveness of both councils is significantly varied, ranging from a certain minimum required to impact EU activities, which is

${ }^{1}$ The article was written as part of a project sponsored by the National Science Centre, Poland (Narodowe Centrum Nauki, NCN): "The European Council in the process of forming formal and informal competences in the realm of the European Union's external activities", no. 2015/19/B/ HS5/00131 [Artykuł został przygotowany w ramach projektu finansowanego przez Narodowe Centrum Nauki: „Rada Europejska w procesie kształtowania kompetencji formalnych i nieformalnych w zakresie działań zewnętrznych Unii Europejskiej”, nr 2015/19/B/HS5/00131. 
the natural objective of both councils after all, to a maximum (Morawiecki, 1996, pp. 150-167).

The position and specific roles of the EU Council and the European Council have increasingly been violating this division, as they are involved in both horizontal and vertical relations of the above actors of European integration. This position of the two councils in the EU's political system produces an utterly extraordinary and unique formula of powers, which attempts to combine two integration worlds - the intergovernmental and supranational (supra-governmental) worlds - into one. This can be evidenced by the governments of member states exercising their multiple influences on the EU Council and the European Council, which functionally depend on the European Commission and the European Parliament, as well as the European Court of Justice.

\section{Politicization}

The formula of activities performed by the EU Council and the European Council is also part of the development of European integration through its direct link with the process of politicization of the European Union's operations and the agential politicization of its entire internal system. Politicization is also related to the issue of national entities involved in the governance of the EU through the changing participation/share of member states in the management of the European Union and its policies (Schmitter, 1999, pp. 1-3).

The multi-centric politicization of the EU makes it possible to analyze this system in terms of a transactional approach as a dual, complementary relationship between the two main entities of integration: the Council of the European Union and the European Council, which are interdependent and together create systemic properties that neither of them possesses separately. They create a joint system of roles, functions and features that they do not have on their own (as individual integration entities). Therefore, in this case, we are dealing with a new political (politicized, nontechnocratic) 'technology' of exercising power and its division should be examined in the horizontal and vertical dimensions (Deutsch, 1968, pp. 224 et seq.).

\section{Checks and balances}

If the relationship between the EU Council and the European Council in the context of the horizontal division of power is based on a system of checks and balances, the emphasis must be on balance rather than on the separation of authorities/entities exercising power. For this reason, the powers and authority of the states and of the European Union are to some extent mixed up in this relational formula, and they overlap. At the same time, each entity has decision-making powers creating a mechanism of political influence. The powers of the EU Council and the European Council are separated in terms of institutions (structures and personnel) but not of functions, because their powers are interrelated. The competition for power here results in its being shared, 
which is based on the 'joint exercising' of power and thus the joint performance of certain systemic functions, tasks and roles. The powers of one authority should not be performed directly or completely by any of the remaining authorities, and none of the authorities should gain a definite advantage over the others. This should be the message for both the presidency of the EU Council and for the President of the European Council, as well as for members of both councils.

\section{Europeanization and internationalization of the EU Council and the European Council}

\section{Europeanization}

European integration is associated with the process of communitarization (unionization) of politics, aiming to change the roles of the EU Council and the European Council in shaping the new systemic forms of integration that are rooted in the process of Europeanization, which is becoming another law of the development, intensification, and by this token of the dynamics of European integration.

Europeanization means that organized collective entities such as the EU Council and the European Council (or the EU Council and the European Council treated as one) adopt and implement European rules, procedures and standards by incorporating them in their internal system. It also involves the spreading, propagation (distribution and redistribution) and alignment of values, information, institutions, norms, models and attitudes. Europeanization is also a process of transfer of knowledge, innovation and, as a consequence, of internal governance models.

Under the influence of changes in the integration system, Europeanization ceases to be a voluntary process increasingly becoming the process of incremental, gradual, formalized adaptation and incorporation of the acquis communautaire and the acquis politique of the EU into the legal and political systems of member states and of the European Union itself.

The specific feature of Europeanization involves the assumption that the same entities (here the EU Council and the European Council) can be both a source of Europeanization and undergo Europeanization themselves. Political life (including the language of politics), administration and economy are specific areas subject to Europeanization. In political life, it is manifested in particular as the spreading of organizations, the rules or values and principles related to their protection. Members of both councils and the administrations of both institutions are subject to Europeanization.

Europeanization through the EU's governance institutions, which both councils are, involves progressing integration. This means integration encompassing the elements that used to be 'external' for EU member states. This demonstrates that no area of the political life of member states can survive in isolation from integration. In this sense, Europeanization is the opposite of closing oneself off and adhering to autarky. Therefore, both councils play important balancing as well as stimulating roles in European integration. 


\section{Europeanization between foreign policy and European policy}

European policy is becoming increasingly dependent on currents that do not stop at national borders and call for a collective response from different governments that can take less and less liberty to act sovereignly. In the context of the presidency, the Europeanization of states limits the freedom of governments in shaping their foreign and domestic policies, and narrows down the selection of desired options in the internal and international/European area. As a consequence, the presence of the EU Council and the European Council makes member states realize that they are increasingly forced to take into account the needs and interests of the outside world, which encourages them to cooperate, coordinate actions and implement mutually beneficial solutions.

Due to Europeanization, in the course of the EU Council and the European Council preparing and implementing political leadership within the EU, member states (as well as candidate countries) seek ways to achieve their goals and interests by working together, aligning and agreeing positions rather than by resorting to selfish activities. The Europeanization of politics, law and economy is becoming a permanent element of both councils' activities. As a result, member states 'unlearn' to act on their own (especially in a centralized EU environment), because it becomes too difficult and expensive for them. Disputes and conflicts have to be resolved by peaceful measures, primarily through negotiation and compromise, using jointly developed standards of conduct.

\section{Internationalization}

Internationalization leads to the greater international interdependence of the states gathered in the EU Council and the European Council. Such growing interdependencies in turn enhance, extend and deepen Europeanization processes. From an analytical point of view, European interdependencies can also be said to result from internationalization processes that go far beyond the EU system.

The above analysis clearly shows that, nowadays, interdependencies are among the basic determinants of the external activities of states. In the context of the role and tasks of the EU Council and the European Council, interdependencies should be treated as a consequence of the deepening internationalization of member states. This is because intergovernmentalism and relations between the EU and its environment have led to an unprecedented intensification of member states' activities in the area of external policy, outside the European Union, too. Unusual interactions and connections emerge between the EU Council and, especially, the European Council (including its president and members), and the outside world. In recent years, since the Lisbon Treaty came in force, both councils have been engaging far more forces and resources in their international activities. They have been trying to be part of both European and global relations. With the help of the High Representative for Foreign Affairs and Security Policy, they have clearly opened the EU to the world even more. This is attracting interest from European and global public opinion, and is helping to strengthen their image and position in international relations. 


\section{Penetration and permeation of the determinants of the EU Council and the European Council activity in the systemic approach}

\section{Penetration and the EU's modus operandi}

In the academic literature, the process of penetration or permeation is attributed great importance in examining the activity of the EU Council and the European Council. Permeation is about the influence one system exerts on the internal operations of another system. For the purposes of this study, permeation is not defined in terms of pressure, but as saturation and systemic diffusion. Therefore, the process of permeation occurs primarily when participants in one system (the European Council) become participants in the political activities in another system (the EU Council). The elements of one system are present in another, including by transferring elements of one system to another (Czachór, 2010b, pp. 77-107).

As part of the modus operandi of the EU, member states in both councils have provided themselves with a wide range of political and legal instruments to enable mutual penetration. It is assumed to be interdependent, diverse and mixed; it is symmetrical in the area of intergovernmental cooperation, and asymmetrical in the supranational area. On the one hand, the integration system is strongly influenced by the operations and decisions of the EU Council, on the other, it is also penetrated by member states that will not give up their permanent presence in the European Union system through their presence in the European Council.

Permeation here is formal and voluntary, based on provisions in treaties and other regulations. This does not necessarily mean that penetration processes pose a threat to the existence of the system. The more so as, in this case, we are dealing with the institutionalization of penetration. On the one hand, the EU Council consists of representatives (ministers) of member states (the EU Council is intergovernmental). On the other hand, the EU Council largely makes supranational decisions by a qualified majority. This is particularly evident when establishing regulations that are direct and binding for all member states. A similar process takes place in the European Council, where the principle of unanimity (consensus) prevails nevertheless (Czachór, 2010a, pp. 212-238).

Penetration can also be informal, which can be seen, for example, in the many mechanisms of changes introduced outside treaties that COREPER or EU Council working groups employ in the course of their work. The permeation of member states' influence or interests into the institutional and decision-making system of the EU dominates here. Here, it is clear that member states have imposed many restrictions on the institutions of the European Union, including the EU Council, thereby impeding their informal permeation into member states' systems. Member states have also carefully considered and planned how to provide themselves with a wide spectrum of such measures.

A specific kind of penetration and permeation occurs also in relations between the EU Council and the European Council on the one hand, and the European Commission and the European Parliament on the other. 


\section{Political legitimization of the authority of the EU Council and the European Council}

\section{New forms of legitimization}

Resolving to establish and develop the European Union, member states decided that European integration needed new forms of legitimization, making it possible to go far beyond the area of operations typical of classic international organizations. Here, legitimization is a privilege enjoyed by the EU Council and the European Council to take actions approved by all recipients of these actions. Legitimization is also a process of political justification, sanctioning and motivating the behavior of the EU and its entities, including member states and their representations in the system (Czachór, 2010a, pp. 212-238).

Legitimization concerns not only European integration, but also its governance, and is closely related to the more or less effective performance of the tasks of the EU Council and the European Council (including the distribution of political decisions and values) which are considered the common interest of its members. Legitimization occurs at multiple levels and involves shifting loyalty from the level of member states to that of the EU and Community, as well as a shift in the opposite direction. For this to be possible, the benefits of participating in the integration system at the intergovernmental and Community levels must outweigh the benefits of remaining outside the system. In this perspective, the combined subsystem of the EU Council and the European Council can be perceived as a kind of political and regulatory authority, or an 'organization/institution with a specific legitimizing purpose' (Wallace, 1996, pp. 439-460).

\section{Result-oriented legitimization}

The result-oriented legitimization of the EU Council and the European Council lies in their ability to accomplish goals and solve problems in an efficient and effective manner. The greater this ability, the more their subsystem is legitimized. However, the development of the European Union is not only characterized by the intensifying pursuit of effective procedures, but also by the ongoing and collective search for an effective and transparent framework allowing the results to be recognized as legitimate.

The legitimization provided by the EU Council and the European Council gains importance in crisis situations occurring between entities or actors of the system, especially regarding their powers (mainly in relations with the European Commission) in the field of solving problems. The activity resulting from a different in way of overcoming tensions or crisis situations in the European Union is unlike what occurs in a similar situation in member states. This results from a different decision system and the foundation of legitimacy (Stemplowski, 2001, pp. 133 et seq.). 


\section{Dual legitimization}

For the purpose of this analysis, the authority of the EU Council and the European Council can also be seen as a sophisticated system of dual legitimization. Operations of both institutions are justified by state authorities on the one hand, and by the whole of the EU's (communitarized, Europeanized) internal apparatus (mainly the General Secretariat) on the other.

The legitimization of the authority of the EU Council and the European Council is associated with certain functions that support exercising this authority. The regulatory function is about controlling integration processes according to the rules adopted in treaties and other regulations. The mediation function involves conflict resolution and mediation regarding conflicting interests of EU countries and institutions. The adaptive function consists of, among others, improving operations of institutions and expanding the foundations of the integration system. The innovative function is about introducing new operating rules and mechanisms into the system and its surroundings.

The adaptive function deserves particular attention, which is directly associated with adapting the system to the permanent change taking place in the European Union, both in terms of its European governance and the admission of new members. Adaptation is also important for the stability of European integration. It helps to neutralize any attempts to change the structure of powers.

One of the important legitimizing functions of the authority of both institutions is their ability to work out consensus over the political and party divisions in the EU. In practice, this ability varies, especially during crises in the EU.

\section{How to build the mission of the EU Council and the European Council. Axiological aspects of the process of creating authority and political decisions and the dissemination of their priorities}

\section{Axiology of the EU Council and the European Council}

In the system of European integration the EU Council and the European Council, whether they want it or not, are part of the process of creating a political community based on values. This is extremely important in the context of developing a mission, and then the agenda and priorities of both institutions, which cannot be merely guided by the national interests of member states.

Today the axiology of the EU Council and the European Council may be an element of the survival and continuation of European integration. The success of such an approach depends on a conjunct combination of the conventional concept of a political coordination system (understood as intergovernmental) and opening up to the pursuit of a joint European good on the basis of an ongoing reconciliation of goals and values, and in the practice of integration - through consensual agreement on specific priorities, objectives and tasks.

Due to the above, the combined authority of both councils can be defined in terms of the process of coordination and governance of not only a 'national good'/'state 
good' but also that of a "European good and common reflection (the outcome of European deliberation, reflection and focus)" functioning within a "European public space" based on shared preferences and a political program (Habermas, 1996, p. 13).

\section{Common European good}

The common European good, analyzed from the point of view of the role of both institutions, could involve a combination of the collective (political and economic) interests of member states with the common values expressed by the supranational and intergovernmental composition of both councils.

In this light, the following values can be distinguished here, important both for the EU Council and the European Council:

- unity - which is expressed through working out and presenting a joint and uniform standpoint;

- solidarity - which pertains to members of the EU Council and the European Council pledging to jointly and simultaneously fulfill their commitments, provide each other with assistance and jointly represent their interests. The departure from this value/principle, especially due to the growing pressure on accepting the opt-out policy, has led to the principle of closer cooperation (enhanced cooperation) having been introduced to the treaties;

- coherence - developing a joint message to member states and the outside world.

\section{Conclusions}

1. The authority of the Council of the European Union and the European Council is located both in the political system of the European Union and the political systems of member states. This makes the two councils unique institutions that combine two important methods of integration: the intergovernmental and communitarian (supranational) methods.

2. Both councils are part of the decision-making process in both member states and the European Union. This process is not a technocratic or apolitical formula for exercising power. Like other integration procedures and phenomena, it undergoes politicization and democratization.

The politicization of the EU Council and the European Council applies to the level of both the states (governments) and the European Union. On the one hand, both institutions are used by member states as an element of their internal political games, and on the other one, they become very important in 'playing out' national preferences, 'haggling' between the representatives of member state governments, and in intergovernmental inter-state negotiations, which abound in confrontation, rivalry and competition.

3. The exercise of power and political leadership in the EU by the EU Council and the European Council is an excuse for a serious, internal debate on the future place of both institutions in a (hopefully) post-crisis EU. 
4. The determination of the current and future agenda and priorities of the EU Council and the European Council and their dissemination, as well as public discourse regarding the core of their presidency in the European Union are invariably affected by the following factors:

- political stability and economic condition of the EU, especially in the times of global and European crisis;

- factual knowledge and logistic preparation of EU and national public administrations;

- political/party consensus (or lack thereof) regarding the present and the future of integration;

- the attitude of governments and their leaders to European integration;

- the negotiating capability of both councils and their ability to strike the necessary compromises;

- the ability to express common interests at the European level;

- the position of the European Union in the world;

- the effectiveness of government cooperation with internal bodies (Secretariat General, COREPER);

- the correspondence between political arrangements and their implementation as regards political decisions and EU legislation.

\section{Bibliography}

Alexandrova P., Carammia M., Timmermans A. (2013), EU High Politics - the Policy Agenda of the European Council, 1975-2011, in: The Commanding Heights of the European Union. The European Council and the rotating presidencies: competition or collaboration?, eds. F. Foret, Y. S. Rittelmeyer, London.

Borkowski P. J. (2007), Polityczne teorie integracji międzynarodowej, Warszawa.

Bocquillon P., Dobbels M. (2014), An elephant on the 13th floor of the Berlaymont? European Council and Commission relations in legislative agenda setting, "Journal of European Public Policy", XXI(1).

Carammia M., Alexandrova P., Princen S. (2013), Analyzing the policy agenda of the European Council, "Perspectives on Europe", 42(2).

Czachór Z. (2013), Kryzys i zaburzona dynamika Unii Europejskiej, Wydawnictwo Elipsa, Warszawa.

Czachór Z. (2012), Bilans dokonań polskiej prezydencji na przykładzie aktywności premiera Donalda Tuska, in: Prezydencja w Radzie Unii Europejskiej. Bilans polskich doświadczeń. Materiały z konferencji KSAP, 11 stycznia 2012 r., eds. J. Czaputowicz, Z. Czachór, Wydawnictwo KSAP, Warszawa.

Czachór Z. (2012a), Prezydencja Rady Unii Europejskiej - wielowymiarowe wyzwanie dla państwa członkowskiego, in: Unia Europejska po traktacie z Lizbony. Pierwsze doświadczenia i nowe wyzwania, ed. P. Tosiek, Wydawnictwo UMCS, Lublin.

Czachór Z. (2011), Politologiczne i polityczne uwarunkowania prezydencji Polski w Radzie Unii Europejskiej, in: Prezydencja w Unii Europejskiej. Polska 2011, ed. A. Nowak-Far, Oficyna Wydawnicza Szkoły Głównej Handlowej, Warszawa.

Czachór Z. (2011a), Prezydencja w Unii Europejskiej i jej priorytety. Analiza politologiczna, in: Priorytety prezydencji Polski w Radzie Unii Europejskiej, eds. Z. Czachór, T. R. Szymczyński, Wydawnictwo PWN, Warszawa. 
Czachór Z. (2010), Demokracja i legitymizacja władzy w UE, in: Pytania o Europę. Opinie ekspertów, ed. I. A. Szyszko, Przedstawicielstwo Komisji Europejskiej, Warszawa.

Czachór Z. (2010a), Prezydencja państwa członkowskiego a system polityczny Unii Europejskiej. Podstawowe uwarunkowania, in: Prezydencja w Unii Europejskiej. Instytucje, prawo i organizacja, ed. A. Nowak-Far, Oficyna Wydawnicza Szkoły Głównej Handlowej, Warszawa.

Czachór (2010b), Proces kreowania i upowszechniania priorytetów prezydencji na przyktadzie Polski, in: Prezydencja w Radzie Unii Europejskiej, ed. K. A. Wojtaszczyk, Oficyna Wydawnicza ASPRA-JR, Warszawa.

Czachór Z. (2004), Zmiany i rozwój w systemie Unii Europejskiej po Traktacie z Maastricht, Wydawnictwo Atla 2, Wrocław.

Delledonne G. (2014), The European Council after Lisbon: A review article, "Perspectives on Federalism", vol. 6, issue 3 .

Deutsch K. W. (1968), Die Analyse internationaler Beziehungen. Konzeption und Probleme der Friedensforschung, Frankfurt a. M.

Gałganek A. (2012), Anarchia versus hierarchia w nauce o stosunkach międzynarodowych, in: Wokót teorii stosunków międzynarodowych, eds. W. Micha, J. Nowak, Wydawnictwo UMCS, Lublin.

Giering C. (1997), Europa zwischen Zweckverband und Superstaat. Die Entwicklung der politikwissenschaftlichen integrationstheorie im Prozess der europäischen Integration, Europa-Union Verlag, Bonn.

Habermas J. (1996), Nim pojawi się ustrój europejski, "Gazeta Wyborcza", 6-7 January.

Jaskulski A. (2007), System polityczny Unii Europejskiej po Traktacie ustanawiajacym Konstytucje dla Europy, Master's dissertation, WNS UAM, Poznań.

Johnston M. T. (1994), The European Council: Gatekeeper of the European Community, Boulder.

Morawiecki W. (1996), Ponadpaństwowy i międzynarodowy charakter Unii Europejskiej, in: Państwa narodowe w euroatlantyckich strukturach, ed. J. Fiszer, Poznań-Warszawa.

Moravcsik A. (1993), Integrating International and Domestic Theories of International Bargaining (Chapter One), in: Double-Edged Diplomacy: International Bargaining and Domestic Politics, eds. P. B. Evans, H. K. Jacobson, R. D. Putnam, Berkeley.

Pollack M. A. (2010), Theorizing EU Policy-Making, in: Policy-Making in the European Union, eds. H. Wallace, M. A. Pollack, A. R. Young, Oxford University Press, Oxford.

Rada Europejska, Konkluzje, 1-2 marca 2012 r., EUCO 4/3/12, Bruksela 8 maja 2012 r.

Rada Europejska, Konkluzje, 28-29 czerwca 2012 r., EUCO 76/12, Bruksela, 29 czerwca 2012 r.

Rada Europejska, Konkluzje, 18-19 października 2012 r., EUCO 156/12, Bruksela, 19 października $2012 \mathrm{r}$.

Rada Europejska, Konkluzje, 13-14 grudnia 2012 r., EUCO 205/12, Bruksela, 14 grudnia 2012 r.

Rada Europejska, Konkluzje, 28-29 czerwca 2012 r., EUCO 76/12, Bruksela, 29 czerwca 2012 r.

Rada Europejska, Konkluzje, 14-15 marca 2013 r., EUCO 23/13, Bruksela 14 marca 2013 r.

Rada Europejska, Konkluzje, 22 maja 2013 r., EUCO 75/1/13, Bruksela 23 maja 2013 r.

Rada Europejska, Konkluzje, 27-28 czerwca 2013 r., EUCO 104/2/13, Bruksela 28 czerwca $2013 \mathrm{r}$.

Rada Europejska, Konkluzje, 24-25 października 2013 r., EUCO 7/1/14, Bruksela 25 października $2013 \mathrm{r}$.

Rada Europejska, Konkluzje, 19-20 grudnia 2013 r., EUCO 217/13, Bruksela 20 grudnia 2013 r.

Rada Europejska, Konkluzje, 20-21 marca 2014 r., EUCO 7/1/14, Bruksela 21 marca 2014 r.

Rada Europejska, Konkluzje, 26-27 czerwca 2014 r., EUCO 79/14, Bruksela 27 czerwca 2014 r. 
Rada Europejska, Pięćdziesiąt lat spotkań na szczycie, Sekretariat Generalny Rady, Luksemburg 2012.

Rosamond B. (2000), Theories of European Integration, Basingstoke-New York.

Schmitter P. C. (1999), Reflections on How and Why the EU Should Be Democratized, Vorbereitet für die gemeinsame Tagung des Kulturwissenschaflichen Instituts, Essen, und des Arbeitskreises Europäische Integration, Bonn, Stand und Entwicklung theoretischer Konzepte zum europäischen Integrationsproze $\beta$, am 23-24 September, AEI Verlag, Essen.

Schoutheete P. (2012), The European Council and the Community Method, "Notre Europe Policy Paper", no. 56.

Schoutheete P., Wallace H. (2016), Study on the European Council, "Research and European Issues" 19, http://www.notre-europe.eu/uploads/tx_publication/Etud19-en.pdf.

Stemplowski R. (2001), Wzmocniona wspótpraca a uniwersalizm w Unii Europejskiej, in: Traktat Nicejski, ed. A. Podraza, Towarzystwo Naukowe Katolickiego Uniwersytetu Lubelskiego, Lublin.

Szczerba-Zawada A. (2015), Między kompromisem a konsensusem. Modus decidendi Rady Europejskiej, in: Procedury decyzyjne Unii Europejskiej, eds. J. Galster, A. Szczerba-Zawada, Warszawa.

Tallberg J. (2008), Political Bargaining in the European Council, "Journal of Common Market Studies", XLVI(3).

Tallberg J. (2003), The Agenda-Shaping Powers of the EU Council Presidency, "Journal of European Public Policy", vol. 10, no. 1.

Wallace W. (1996), Governance without Statehood. The Unstable Equilibrium, in: Policy-Making in the European Union, eds. H. Wallace, W. Wallace, Oxford University Press, Oxford.

Weiler J. H. H., Haltern U., Mayer F. (1995), European Democracy and its Critics - Five uneasy Pieces, Harvard Jean Monnet Working Papers.

Werts J. (2008), The European Council, London.

Wessels W. (1980), Der Europäische Rat: Stabilisierung statt Integration? : Geschichte, Entwicklung und Zukunft der EG-Gipfelkonferenzen, Bonn.

Wessels W. (2013), The European Council as the key (international) player, Paper presented at the EUSA 13th Biennial Conference, Baltimore, Maryland.

Zasady organizacji prac na szczytach strefy euro (2012), Sekretariat Generalny Rady, Luksemburg.

\section{Summary}

If the relationship between the EU Council and the European Council in the context of the horizontal division of power is based on a system of checks and balances, the emphasis must be on balance rather than on the separation of authorities/entities exercising power. For this reason, the powers and authority of the states and of the European Union are to some extent mixed up in this relational formula, and they overlap. At the same time, each entity has decision-making powers creating a mechanism of political influence. The powers of the EU Council and the European Council are separated in terms of institutions (structures and personnel) but not of functions, because their powers are interrelated. The competition for power here results in its being shared, which is based on the 'joint exercising' of power and thus the joint performance of certain systemic functions, tasks and roles. The powers of one authority should not be performed directly or completely by any of the remaining authorities, and none of the authorities should gain a definite advantage over the others. This should be 
the message for both the presidency of the EU Council and for the President of the European Council.

Key words: Council of the EU, European Council, political system, politicization and democratization of the EU, political legitimization of authorities, priorities, penetration and permeation, Europeanization and internationalization

\section{System polityczny Unii Europejskiej a politologiczne i polityczne uwarunkowania aktywności Rady UE i Rady Europejskiej}

\section{Streszczenie}

Jeżeli przyjąć, iż relacja Rada UE - Rada Europejska w kontekście poziomego podziału władzy opiera się na systemie checks and balances, czyli systemie „hamulców i równoważników", nacisk musi zostać położony na równowagę, a nie oddzielenie władz/podmiotów ją wykonujących. Dlatego kompetencje i władza państwa i Unii Europejskiej są w formule tej relacji do pewnego stopnia wymieszane i nakładają się na siebie. Jednocześnie każdy z podmiotów dysponuje uprawnieniami decyzyjnymi, tworząc mechanizm politycznego oddziaływania. Władza Rady UE i Rady Europejskiej odseparowane są w sensie instytucjonalnym (strukturalnym i personalnym), ale nie funkcjonalnym, gdyż w rzeczywistości ich uprawnienia są ze sobą powiązane. Wynikiem konkurencji o władzę jest tu jej dzielenie, które opiera się na „wspólnym korzystaniu", a więc łącznym wykonywaniu jej funkcji, zadań i ról. Uprawnienia jednej władzy nie powinny być bezpośrednio ani całkowicie wykonywane przez żadną z pozostałych władz i żadna z władz nie powinna uzyskać zdecydowanej przewagi nad innymi. To przesłanie towarzyszyć musi zarówno prezydencji Rady UE, jak i Przewodniczącemu Rady Europejskiej.

Słowa kluczowe: Rada UE, Rada Europejska, system polityczny, polityzacja i demokratyzacja UE, legitymizacja polityczna władzy, priorytety, penetracja i przenikanie, europeizacja i internacjonalizacja 